\title{
Lypsylehmien energiatehokkuuden perinnölliset tunnusluvut ja yhteydet maidontuotantoon, kuiva-aineen syöntiin, elopainoon ja kuntoluokkaan
}

\author{
Anna-Elisa Liinamo ${ }^{1)}$, Päivi Mäntysaari ${ }^{2)}$ ja Esa Mäntysaari ${ }^{1)}$ \\ ${ }^{1)}$ MTT Biotekniikka- ja elintarviketutkimus, biometrinen genetiikka, 31600 Jokioinen, \\ etunimi.sukunimi@mtt.fi \\ ${ }^{2)}$ MTT Kotieläintuotannon tutkimus, 31600 Jokioinen, etunimi.sukunimi@mtt.fi
}

\section{Tiivistelmä}

Rehukulut ovat maidontuotannon merkittävin kustannuserä, ja lypsylehmien kyky muuttaa rehuenergiaa tehokkaasti maidon energiaksi on tärkeää sekä maidontuotannon taloudellisuuden että ympäristövaikutusten kannalta. Energiatehokkuuden ottaminen suoraan jalostustavoitteeksi saattaisi parantaa maidontuotannon taloudellisuutta ja vähentää sen ympäristövaikutuksia vaarantamatta samalla lehmien terveyttä.

Tässä tutkimuksessa hyödynnettiin MTT:n Rehtijärven koetilalta vuosina 1998 - 2009 kerättyä aineistoa, joka käsitti 291:n ensimmäistä tuotantokauttaan lypsävän ASMO-ydinkarjaan kuuluvan lehmän rehunkulutus-, elopaino-, kuntoluokka- ja tuotostiedot laktaatioviikoilta 2 - 30. Näiden tietojen perusteella aineistosta arvioitiin perinnölliset tunnusluvut rehutaulukoiden mukaan arvioidulle energiataseelle ja lehmän energiatehokkuutta kuvaavalle aineiston perusteella lasketulle energianmuuntoyhtälön residuaalille eli “jäännösenergiankulutukselle”. Lisäksi arvioitiin näiden ominaisuuksien perinnölliset yhteydet lehmien maidontuotannon, kuiva-aineen syönnin, elopainon ja kuntoluokan kanssa. Ominaisuudet analysoitiin satunnaisregressiomallilla, jossa kiinteinä tekijöinä olivat lehmän poikimavuosi-kuukausi ja poikimaikä ja satunnaistekijöinä lehmän pysyvät ympäristötekijät ja eläintekijät mallinnettuina toisen asteen Legendre-polynomeilla.

Energiataseen ja energiatehokkuuden periytymisasteen arviot olivat korkeimmat heti lypsykauden alussa, putosivat lähelle nollaa laktaatioviikkoina 10 - 20, ja alkoivat sen jälkeen taas nousta kohti laktaatioviikkoa 30. Korkeimmillaan periytymisasteen arviot energiatehokkuusmitoille olivat 0,20 - 0,35. Kumpikin mitta vaikutti koostuvan kahdesta suureksi osaksi erillisestä ominaisuudesta, ja energia suuntautuukin lypsykauden alussa etupäässä maidontuotantoon ja myöhemmässä vaiheessa enemmän lehmien kudosenergiavarastojen täydennykseen ja kasvuun. Energiamittojen välinen geneettinen korrelaatio oli voimakas ja positiivinen, ja yleisesti molempien mittojen geneettiset korrelaatiot muiden ominaisuuksien kanssa olivat samansuuntaisia: kohtalaisia tai voimakkaita ja positiivisia kuiva-aineen syönnin, elopainon ja kuntoluokan kanssa, ja lypsykauden alussa kohtalaisia ja negatiivisia mutta laktaatioviikoilta 6-7 eteenpäin jo positiivisia ja korkeimmillaan kohtalaisia maidontuotannon kanssa. Näin ollen energiatehokkuudeltaan laskennallisesti parempien lehmien suosiminen jalostusvalinnassa johtaisi epäsuorasti elopainoltaan ja rehunkulutukseltaan pienempiin lehmiin, mutta myös lehmien lisääntyneeseen kudosenergian hyödyntämistarpeeseen ja jyrkempään lypsykäyrän muotoon.

Asiasanat: lypsylehmät, rehun hyväksikäyttö, perinnölliset tunnusluvut, jalostustavoitteet 


\section{Johdanto}

Rehukulut ovat maidontuotannon merkittävin kustannuserä, ja lypsylehmien kyky muuttaa rehuenergiaa tehokkaasti maidon energiaksi on tärkeää sekä maidontuotannon taloudellisuuden että ympäristövaikutusten kannalta. Keskimäärin lypsylehmät hukkaavat rehun metabolisoituvasta energiasta 10 \% pötsikäymisessä syntyvän metaanin muodossa, mutta eläinten välillä on suuria eroja niiden energian hyväksikäyttökyvyssä ja metaanin tuotantomäärissä.

Perinteiset jalostusohjelmat ovat pyrkineet parantamaan lehmien energiatehokkutta keskittymällä niiden maidontuotanto-ominaisuuksien kehittämiseen, minkä seurauksena lehmien metaanissa hukkaama energia on jakautunut useampia tuotettuja maitokiloja kohti parantaen maidontuotannon laskennallista bruttoenergiatehokkuutta huomattavasti. Samaan aikaan kuitenkin lehmien rehun syöntikyky ei ole kyennyt kasvamaan maidontuotannon vaatimusten tahdissa, jolloin lehmien riippuvuus kudoksiinsa varastoidun energian mobilisoinnista lypsykauden huipputuotosvaiheessa on kasvanut lisäten samalla riskiä terveys- ja hedelmällisyysongelmiin. Energiatehokkuuden ottaminen suoraan jalostustavoitteeksi saattaisi parantaa maidontuotannon taloudellisuutta ja vähentää sen ympäristövaikutuksia vaarantamatta samalla lehmien terveyttä. Lehmien rehunkulutuksen mittaaminen on kuitenkin käytännön olosuhteissa vaikeaa ja kallista, minkä vuoksi energiatehokkuutta ja siinä ilmenevää geneettistä vaihtelua on tutkittu lypsylehmillä vielä vähän.

Tämän tutkimuksen tarkoituksena oli arvioida lehmien energian hyväksikäyttökykyä kuvaavien mittojen perinnölliset tunnusluvut ja yhteydet lehmien maidontuotantoon, rehunsyöntiin, elopainoon ja kuntoluokkaan lypsykauden eri vaiheissa suomalaisesta ayrshireaineistosta.

\section{Aineisto ja menetelmät}

Tutkimuksessa hyödynnettiin MTT:n Rehtijärven koetilalta vuosina 1998 - 2009 kerättyä aineistoa, joka käsitti 291:n ensimmäistä tuotantokauttaan lypsävän ASMO-ydinkarjaan kuuluvan lehmän rehunkulutus-, elopaino-, kuntoluokka- ja tuotostiedot laktaatioviikoilta 2 - 30. Viikkohavaintoja oli aineistossa yhteensä 7 714. Aineisto oli kerätty neljän eri ruokintakokeen aikana, joista kolmea ensimmäistä on kuvannut tarkemmin Mäntysaari ym. (2003; 2004; 2005) ja neljättä Mäntysaari ym. (2012).

Aineiston lehmät polveutuivat 72 eri isästä ja 243 emästä. Koska lehmät olivat ydinkarjaeläimiä, ne olivat varsin läheisesti sukua keskenään sekä isän että emän puolelta sukupuutaan. Suurin isänpuoleinen puolisisarryhmä aineistossa käsitti 21 eläintä. Aineistossa oli myös 9 emä-tytärparia joilta oli molemmilta havaintoja, sekä 43 vastaavaa emä-tyttärentytärparia. Analyyseissä käytetty koko sukutiedosto sisälsi 943 eläintä ja käsitti sukutiedot kaksi sukupolvea taaksepäin aineiston lehmistä.

Lehmien rehunkulutus oli ilmaistu aineistossa viikottaisina keskiarvoina laktaatioviikoille 2 30. Rehunkulutusta ei kuitenkaan mitattu laidunkaudella, joten rehunkulutustiedot puuttuivat laidunkaudelle osuneilta laktaatioviikoilta. Lehmien maitotuotokset mitattiin kahtena päivänä viikossa. Maitoanalyysit maidon rasva-, valkuais- ja laktoosianalyysejä varten oli otettu joko kerran kuussa (ruokintakokeet 1-3) tai viikoittain laktaatioviikoilla 2-8 ja sen jälkeen joka neljäs viikko (ruokintakoe 4). Lehmien elopainot perustuivat rinnanympärysmittoihin kolmen ensimmäisen ruokintakokeen aikana kerätyissä aineistoissa (Mäntysaari et al., 2003; 2004; 2005). Neljännen ruokintakokeen aikana lehmät oli punnittu viikoittain (laktaatioviikot 2-8), joka toinen viikko (laktaatioviikot 9-16) tai joka neljäs viikko (laktaatioviikot 17 - 30). Lehmien kuntoluokka oli arvioitu kahden arvioijan toimesta joka neljäs viikko (ruokintakokeet 1-3) tai joka toinen viikko (ruokintakoe 4) poikimisesta alkaen. Viikoittaiset keskimääräiset elopainot ja kuntoluokat laskettiin lehmille mitatuista tai punnituista havainnoista käyttämällä Wilminkin funktiota (paino) tai kolmannen asteen regressioyhtälöä (kuntoluokka).

Kerättyjen tietojen perusteella lehmille laskettiin kaksi energiankäyttöä kuvaavaa mittaa. 
Lehmien viikoittainen energiatase (Energy Balance, EB) laskettiin syödyn energian ja ylläpitoon ja maidontuotantoon käytetyn energian erotuksena (ME MJ/pv). Ylläpitoon ja maidontuotantoon käytetty energia laskettiin Rehutaulukoissa (MTT, 2006) annettujen tarvenormien mukaan. Lisäksi laskettiin ns. energianmuuntoyhtälön residuaali eli "jäännösenergiankulutus” (Residual Energy Intake, REI) vähentämällä syödystä energiasta maidontuotantoon, ylläpitoon ja kasvuun tarvittava energia sekä lisäämällä painonpudotusta vastaava energia regressiomallilla aineistosta laskettuna. Muut tutkittavat ominaisuudet olivat viikoittainen keskimääräinen energiakorjattu maitotuotos $\mathrm{kg} / \mathrm{pv}$ (ECM), kuivaaineen syönti kg/pv (DMI), elopaino kg (BW) ja kuntoluokka 1-5 (BCS). Aineiston keskiarvot, keskihajonnat ja minimi- ja maksimiarvot on esitetty taulukossa 1.

Aineistosta arvioitiin perinnölliset tunnusluvut satunnaisregressiomallilla, jossa kiinteinä tekijöinä olivat lehmän poikimavuosi-kuukausi ja poikimaikä ja satunnaistekijöinä lehmän pysyvät ympäristötekijät ja eläintekijät mallinnettuina toisen asteen Legendre-polynomeilla. Varianssi- ja kovarianssikomponentit arvioitiin käyttämällä Restricted Maximum Likelihood -menetelmää ja VCE6-ohjelmaa (Groeneveld, 2008).

Taulukko 1. Tutkittujen ominaisuuksien keskiarvot (k.a.), keskihajonnat (SD) ja minimi- ja maksimiarvot.

\begin{tabular}{lrrrrr}
\hline Ominaisuus & Yksikkö & k.a. & SD & Min. & Max. \\
\hline ECM & $\mathrm{kg} / \mathrm{d}$ & 27.20 & 3.75 & 16.40 & 38.10 \\
DMI & $\mathrm{kg} / \mathrm{d}$ & 18.10 & 2.48 & 10.60 & 26.00 \\
BW & $\mathrm{kg}$ & 577.00 & 47.40 & 443.00 & 752.00 \\
BCS & $1-5$ & 3.05 & 0.26 & 2.26 & 4.07 \\
EB & $\mathrm{MJ} \mathrm{ME} / \mathrm{kg}$ & 6.02 & 27.70 & -91.00 & 105.00 \\
REI & $\mathrm{MJ} \mathrm{ME} / \mathrm{kg}$ & 3.52 & 33.29 & -123.68 & 151.31
\end{tabular}

\section{Tulokset ja tulosten tarkastelu}

Energiamittojen periytymisasteen arviot olivat korkeimmat heti lypsykauden alussa, putosivat lähelle nollaa laktaatioviikkoina 10 - 20, ja alkoivat sen jälkeen taas nousta kohti laktaatioviikkoa 30 (Kuva 1). Korkeimmillaan energiamittojen periytymisasteen arviot olivat $0,20-0,35$. Kumpikin mitta vaikutti koostuvan kahdesta suureksi osaksi erillisestä ominaisuudesta, ja energian tarve ja käyttö lypsykauden alussa liittyneekin etupäässä maidontuotantoon ja myöhemmässä vaiheessa enemmän lehmien kudosenergiavarastojen täydennykseen ja kasvuun. Tulokset ovat samansuuntaisia kuin saksalaisessa holstein-rotuisessa sonninemäaineistossa (Hüttman ym., 2009), mutta myös täysin päinvastaisia tuloksia on saatu mm. irlantilaisesta laidunaineistosta (Berry ym., 2007). Berry ym. totesivat kuitenkin myös, että energiatehokkuuden geneettinen vaihtelu oli suurinta laktaation alussa ja lopussa.

Muista ominaisuuksista energiakorjatun maitotuotoksen ja kuntoluokan periytymisasteiden arviot pysyivät varsin vakioina koko laktaation ajan, kun taas elopainon periytymisasteet olivat korkeimmillaan laktaation alussa ja laskivat myöhemmin (Kuva 2). Kuiva-aineen syönnin periytymisasteiden arviot olivat korkeimmillaan laktaatioviikolla 5 ja jälleen viikolla 30 .

Energiamittojen välinen geneettinen korrelaatio oli voimakas ja positiivinen, ja yleisesti molempien mittojen geneettiset korrelaatiot muiden ominaisuuksien kanssa olivat hyvin samansuuntaisia. Geneettiset korrelaatiot olivat kohtalaisia tai voimakkaita ja positiivisia kuiva-aineen syönnin, elopainon ja kuntoluokan kanssa. Maidontuotannon kanssa energiatehokkuusmittojen geneettiset korrelaatiot olivat lypsykauden alussa kohtalaisia ja negatiivisia, mutta laktaatioviikoilta 6- 
7 eteenpäin jo positiivisia ja korkeimmillaan kohtalaisia maidontuotannon kanssa (Kuva 3). Alhaiset geneettiset korrelaatiot maidontuotannon ja energiatehokkuuden välillä lypsykauden alussa liittynevät siihen, että lehmien rehuenergiansaanti ei kyennyt heti vastaamaan nopeasti kasvavaan maitotuotokseen ja saavutti tasapainotilan vasta muutamaa viikkoa myöhemmin. Tulosten perusteella on mahdollista, että korkeatuottoiset lehmät voivat käyttää kudosenergiaa tehokkaammin hyväkseen tämän rehuenergiavajeen aikana.

On myös huomionarvoista, että vaikka fenotyyppisellä tasolla REI ei ole korreloitunut maidontuotannon tai elopainon kanssa laskentatavasta johtuen, geneettiset korrelaatiot näiden ominaisuuksien välillä ovat korkeimmillaan kuitenkin kohtalaisen vahvoja (Kennedy ym., 1993).

Kuva 1. Energiamittojen periytymisasteet laktaatioviikoilla $2-30$.

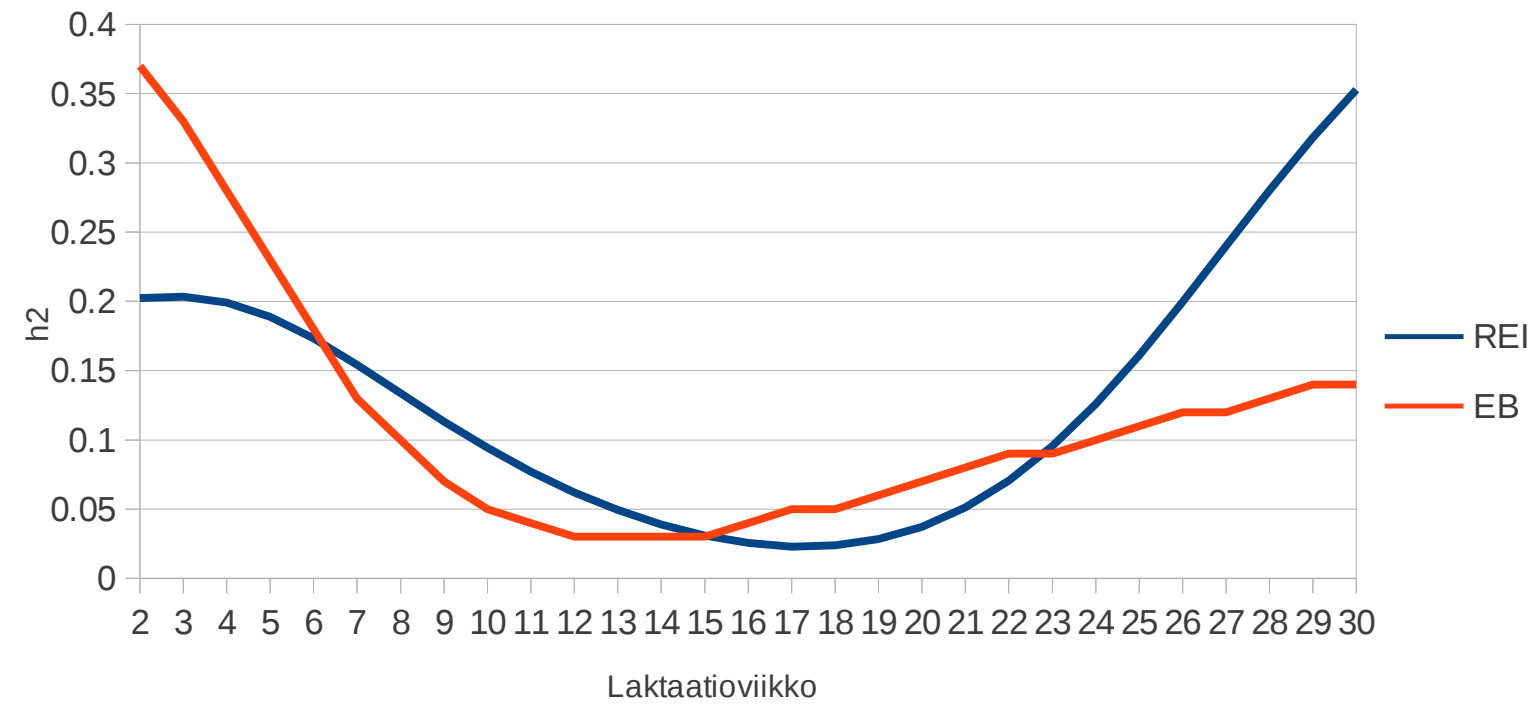

Kuva 2. Muiden tutkittujen mittojen periytymisasteet laktaatioviikoilla 2 - 30.

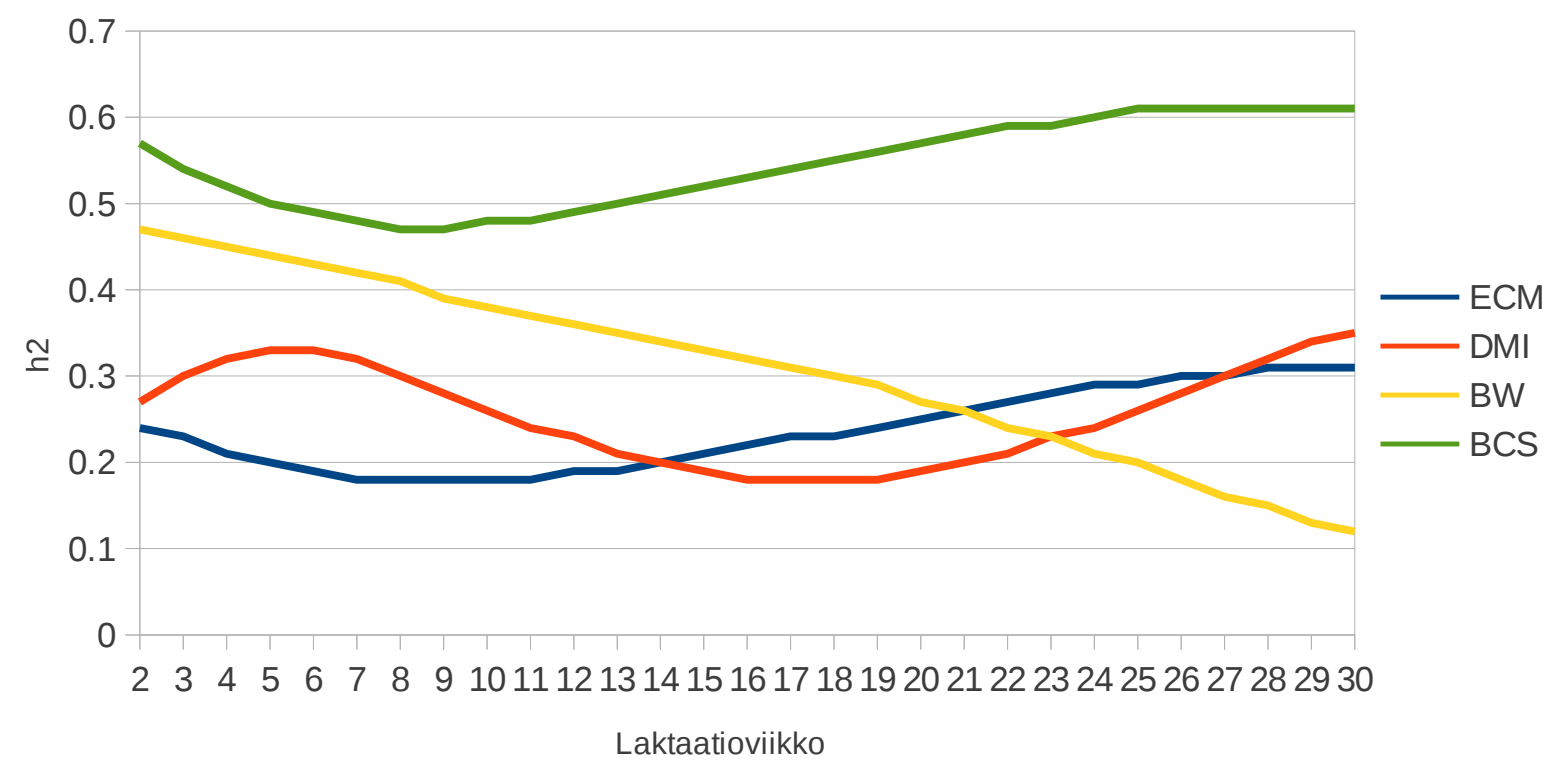


Kuva 3. Energiataseen ja energiatehokkuuden geneettiset korrelaatiot energiakorjatun maitotuotoksen kanssa laktaatioviikoilla $2-30$.

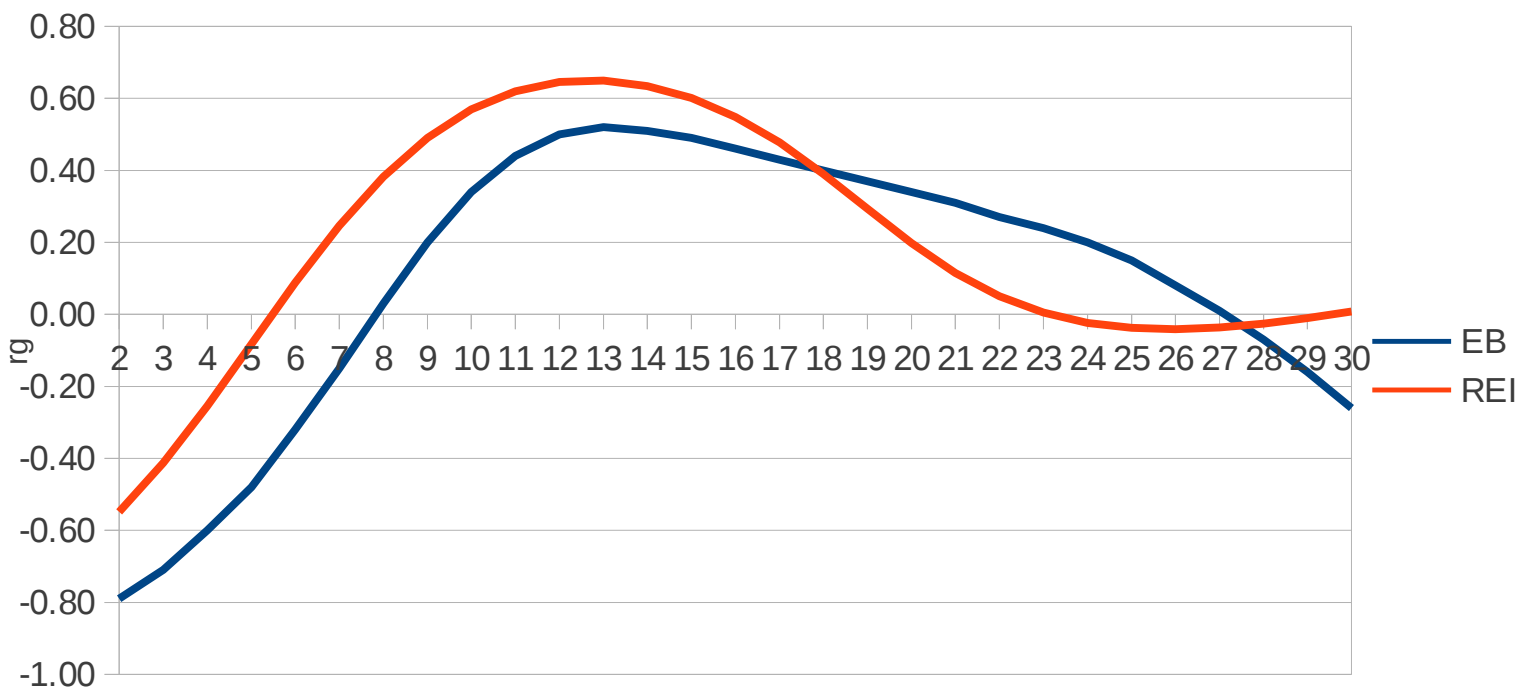

Laktaatioviikko

\section{Johtopäätökset}

Tutkimuksen perusteella lypsylehmien energiatehokkuudessa ilmenee geneettistä vaihtelua, ja energiatehokkuusmittojen periytymisasteiden arviot ovat lypsykauden alussa kohtalaisia. Näin olleen lehmiä olisi mahdollista valita energiatehokkuuden suhteen jopa yksilövalinnalla, mikäli valintakandidaateille olisi käytettävissä rehunkulutustiedot tuotos- ja muiden tietojen ohella. Tulosten perusteella laktaation ensimmäiset viikot ovat lehmille kriittisintä aikaa, jolloin ne parhaiten ilmentävät geneettistä potentiaaliaan sekä rehun syöntiin että rehuenergian tehokkaaseen hyödyntämiseen. Lehmien tulisi käynnistää kiimakiertonsa uudelleen laktaation ensimmäisten viikkojen aikana tullakseen tiineiksi normaalissa aikataulussa, mikä entisestään lisää kiinnostusta kyseiseen ajanjaksoon sekä tutkimuksen että käytännön kannalta. Näin ollen optimaalista olisi tarkkailla energiataseen vajetta lypsykauden alussa, kun taas energian käytön tehokkuus edellyttäisi vähintäänkin toista rehunkäytön mittausta lypsykauden puolen välin jälkeen.

Geneettisten korrelaatioiden perusteella energiatehokkuudeltaan laskennallisesti parempien (= alhaisempi REI) lehmien suosiminen jalostusvalinnassa voisi johtaa epäsuorasti elopainoltaan ja rehunkulutukseltaan pienempiin lehmiin, mutta mahdollisesti myös lehmien lisääntyneeseen kudosenergian hyödyntämistarpeeseen ja lypsykäyrän jyrkentyvään muotoon. Näin ollen nyt tutkittujen energiatehokkuusmittojen hyödyntäminen jalostusohjelmissa ei ole täysin yksiselitteistä, ja lisää tutkimusta tarvitaan vielä mittojen yhteydestä $\mathrm{mm}$. lehmien terveys- ja hedelmällisyysominaisuuksiin. Taloudelliselta kannalta tavoitteena tulisi olla rehuenergian käytön tehostaminen (REI), mutta samalla huolehtien että lehmien "todellinen" energiatase ei laske alle eläimen luontaisen kestokyvyn. 


\section{Kirjallisuus}

Berry, D.P., Horan, B, O’Donovan, M., Buckley, F., Kennedy, E., McEvoy, M. \& Dillon, P. 2007. Genetics of grass dry matter intake, energy balance, and digestibility in grazing Irish dairy cows. J. Dairy Sci., 90:48354845.

Groeneveld, E., M. Kovač \& Mielenz, N. 2008. VCE user's guide and reference manual version 6.0. URL: http://vce.tzv.fal.de/.

Hüttmann, H., Stamer, E., Junge, W., Thaller, G. \&Kalm, E. 2009. Analysis of feed intake and energy balance of high-yielding first lactating Holstein cows with fixed and random regression models. Animal 3:181188.

Kennedy, B., van der Werf, J.H. \& Meuwissen, T.H. 1993. Genetic and statistical properties of residual feed intake. J. Anim. Sci. 71: 3239-3250.

MTT. 2006. Rehutaulukot ja ruokintasuositukset (Feed tables and feeding recommendations) [online]. Jokioinen: MTT Agrifood Research Finland. http://www.mtt.fi/rehutaulukot/. URN:NBN:fi-fe20041449.

Mäntysaari, P., P. Huhtanen, J. Nousiainen \& Virkki, M. 2004. The effect of concentrate crude protein content and feeding strategy of total mized ration on performance of primiparous dairy cows. Livest. Prod. Sci. 85:223-233.

Mäntysaari, P., P. Huhtanen, J. Nousiainen, \& Virkki, M. 2005. The effect of protein-feeding strategy during lactation on performance of primiparous dairy cows fed total mixed ration. Livest. Prod. Sci. 94: 189-198.

Mäntysaari, P., Liinamo, A.-E. \& Mäntysaari, E.A. 2012. Eläinten välinen vaihtelu rehun hyväksikäytössä ayrshire-ensikoilla. Maataloustieteen päivät 2012.

Mäntysaari, P. \& Mäntysaari, E.A. 2010. Predicting early lactation energy balance in primiparous Red Dairy Cattle using milk and body traits. Acta Agric. Scand., Sect. A, 60:79-87

Mäntysaari, P., J. Nousiainen \& Huhtanen, P. 2003. The effect of constant or variable forage to concentrate ratio in total mized ration on performance of primiparous dairy cows. Livest. Prod. Sci. 82: 27-37. 